\title{
Influence of soil water content and soil amendments on trace metal release and seedling growth in serpentine soil
}

\author{
Viraj Gunarathne ${ }^{1}$ - Nishanta Rajakaruna ${ }^{2,3}$ • Udaya Gunarathne ${ }^{1}$. Jayanta Kumar Biswas ${ }^{4} \cdot$ Zach A. Raposo $^{2}$. \\ Meththika Vithanage ${ }^{1}$
}

\begin{abstract}
Purpose This study was conducted to evaluate the synergistic effects of organic amendments and soil water status on trace metal release from serpentine soil.

Materials and methods Two organic amendments, dendro-biochar (BC) and municipal solid waste compost $(\mathrm{CM})$, were added to serpentine soil at four different ratios, specifically 2.5:0.0, 2.5:1.0, 2.5:2.5, and 2.5:5.0\% (w/w). Along with the control (with no organic amendments), each soil treatment was incubated separately under saturated point (SP) and field capacity (FC) water content for 10 days. Subsamples were obtained from each treatment to analyze the bioavailable trace metal concentration and related edaphic parameters, namely total organic carbon (TOC), nitrate $\left(\mathrm{NO}_{3}{ }^{-}\right)$, phosphate $\left(\mathrm{PO}_{4}{ }^{3-}\right)$, and cation exchange capacity (CEC). Then, the soil solution was eluded from each treatment and incubated for 10 days under permanent wilting point (PW). Furthermore, a seed germination test was performed under the different treatments.

Results and discussion Significant reductions $(p<0.05)$ in bioavailable concentration of all four trace metals were observed in all the amendment ratios under all water status treatments (SP, FC, SP-PW, and FC-PW), compared with the control. Furthermore, FC-PW with the highest amendment ratio $(2.5 \% \mathrm{BC}: 5.0 \% \mathrm{CM})$ reduced Ni by $67.6 \%$; FC-PW with $2.5 \% \mathrm{BC}+2.5 \% \mathrm{CM}$ immobilized Mn and Co by 92.1 and $96.9 \%$, respectively, and SP water status with all four amendment ratios immobilized $100 \%$ of bioavailable $\mathrm{Cr}$. Maximum amendment ratio under all four water status enhanced $\% \mathrm{TOC}$ and significantly increased $\mathrm{PO}_{4}{ }^{3-}$ concentration in SP-PW. However, $\mathrm{FC}$ showed comparatively high $\mathrm{NO}_{3}{ }^{-}$concentration than other treatments. Germination index (GI) for mung beans and tomato did not show a significant difference in response to amendment ratios or soil water status; however, SP treatment expressed significantly high seedling vigor (SVI) for mung beans.

Conclusions Treatments of $\mathrm{BC}$ and $\mathrm{CM}$ effectively immobilize the bioavailable fraction of trace metals in serpentine soils. Increasing amendment ratio increases the \% TOC regardless of the soil water status, whereas SP-PW is favorable for the availability of $\mathrm{PO}_{4}{ }^{3-}$, and $\mathrm{FC}$ is favorable for availability of $\mathrm{NO}_{3}{ }^{-}$. The GI for mung beans and tomato seed was not influenced by the soil water status nor by the amendment ratios. However, the SVI of mung bean seedlings was controlled by the soil water status.
\end{abstract}

Keywords Biochar $\cdot$ Compost $\cdot$ Serpentine $\cdot$ Plant nutrients $\cdot$ Remediation $\cdot$ Soil water content $\cdot$ Trace metals

Responsible editor: Kitae Baek

Electronic supplementary material The online version of this article contains supplementary material, which is available to authorized users.

Meththika Vithanage

meththika@ sjp.ac.lk

1 Ecosphere Resilience Research Centre, Faculty of Applied Sciences, University of Sri Jayewardenepura, Nugegoda, Sri Lanka

2 Biological Sciences Department, California Polytechnic State University, San Luis Obispo, CA 93407, USA
3 Unit for Environmental Sciences and Management, North-West University, Potchefstroom, South Africa

4 Enviromicrobiology, Ecotoxicology and Ecotechnology Research Laboratory, Department of Ecological Studies and International Centre for Ecological Engineering, University of Kalyani, Kalyani, West Bengal 741235, India 


\section{Introduction}

Ultramafic rocks and related serpentine soils are distributed all over the world and represent nearly $1 \%$ of surface area of the Earth (Vithanage et al. 2014). Even though these soils show sparse distribution, their occurrence is reported in all major biomes and all the continents except Antarctica (Harrison and Kruckeberg 2008). Natural weathering processes of ultramafic rocks lead to pedogenesis of serpentine soils and sediments characterized by a high metal content (i.e., $\mathrm{Mg}, \mathrm{Ni}, \mathrm{Cr}$, $\mathrm{Co}$, and $\mathrm{Mn}$ ), high $\mathrm{Mg}: \mathrm{Ca}$ ratios, and nutrient poor conditions (Rajapaksha et al. 2012; Vithanage et al. 2014; Kumarathilaka et al. 2016). Rajapaksha et al. (2012) found 6179, 1036, 11,352 , and $121 \mathrm{mg} \mathrm{kg}^{-1}$ respective values for total concentration of $\mathrm{Ni}, \mathrm{Mn}, \mathrm{Cr}$, and $\mathrm{Co}$ in $<2-\mathrm{mm}$ fraction of soil from Ussangoda serpentine outcrop, Sri Lanka. Some of the industrialized and most populated human settlements in North America, Europe, Africa, Southeast Asia, and Australia are on or in close proximity to extensive serpentine outcrops (Brooks 1987; Harrison and Rajakaruna 2011; Kumarathilaka et al. 2016). In addition, some serpentine deposits have been extended into agricultural regions (Ye-Tao et al. 2012; Neilson and Rajakaruna 2015), including in Mouriki-Thiva, Central Greece, where Antibachi et al. (2012) found 621-2639 and $134-856 \mathrm{mg} \mathrm{kg}^{-1}$ of $\mathrm{Ni}$ and $\mathrm{Cr}$ in soil, respectively. Moreover, due to high rainfall and erosion, serpentine soil and sediments can separate from its main body, transport through irrigation systems, and deposit in valleys and lowlands which are used extensively for agriculture (Wei et al. 2018). Ranau Valley in Malaysia was reported to have $\mathrm{Mn}\left(43,063.8 \mathrm{mg} \mathrm{kg}^{-1}\right), \mathrm{Cr}\left(7332.2 \mathrm{mg} \mathrm{kg}^{-1}\right), \mathrm{Ni}$ $\left(6322.3 \mathrm{mg} \mathrm{kg}^{-1}\right)$, and $\mathrm{Co}\left(1004.7 \mathrm{mg} \mathrm{kg}^{-1}\right)$ in paddy soil due to erosion, transport, and sedimentation (Aziz et al. 2015). Similarly, the serpentine sediment deposition in agricultural areas located in floodplains of Whatcom County, Washington, USA, had resulted from a natural landslide associated with headwater areas of the Swift Creek tributary (Baugé et al. 2013).

Due to the presence of elevated levels of trace metals, serpentine soils and sediments can be considered as nonanthropogenic sources of trace metal contamination (Rajakaruna and Baker 2004; Seneviratne et al. 2015). Many studies have found extreme total concentrations of trace metals, especially $\mathrm{Ni}, \mathrm{Cr}, \mathrm{Mn}$, and $\mathrm{Co}$ in serpentine soils in various localities worldwide (Lázaro et al. 2006; Antibachi et al. 2012; Aziz et al. 2015; Galey et al. 2017). However, the total trace metal concentration does not accurately reflect the extent of environmental pollution and ecological risks because trace metals show fractionation among different components of soil (Cheng et al. 2011; Tashakor et al. 2011). Even though the soil is divided into different fractions, including (1) adsorptive and exchangeable, (2) contained in carbonate phase, (3) bound to reducible phases (Fe and Mn oxides),
(4) occluded with organic matter and sulfides, and (5) residual/lattice metals, and the trace metals are distributed among these fractions (Kierczak et al. 2008), the bioavailability, mobility, and toxicity are solely dependent on the amount of trace metal bound in the adsorptive and exchangeable fraction (Kabala and Singh 2001). The study done by Rajapaksha et al. (2012) found $167.6( \pm 6.4)$ and $45.5( \pm 3.0) \mathrm{mg} \mathrm{kg}^{-1}$, respectively, of bioavailable $\mathrm{Ni}$ and $\mathrm{Mg}$ from serpentine sediments. Further, the same study revealed the respective rates of $1.55 \times 10^{-13}$ and $7.89 \times 10^{-14} \mathrm{~mol} \mathrm{~m}^{-2} \mathrm{~s}^{-1}$ of Ni and Mn release into water within $24 \mathrm{~h}$.

Soil moisture regimes have a direct effect on many physicochemical and microbiological qualities of soils, including organic matter content, $\mathrm{pH}$, and electrical conductivity (Van den Berg and Loch 2000; Angle et al. 2003; Gray and Mclaren 2006; Zheng and Zhang 2011) and are indirectly involved in the fractionation of metals and their bioavailability. Zheng and Zhang (2011) demonstrated the effect of hydrological regimes such as field capacity, flooding, and wetting-drying cycles for transformation rates of trace metals among different fractions of paddy soils. The flooding condition of soil contributes to higher transformation rates of trace metals towards stable fractions (i.e., Fe-Mn oxide and organic matter bound) than soil incubated under $75 \%$ of field capacity and soils which are kept under wetting-drying cycles. Trace metal transformation into stable fractions under flooded conditions is governed by increased $\mathrm{pH}$ levels, metal ion precipitation with sulfides, and increased concentration of ion oxides which are induced by the saturated water level (Zheng and Zhang 2011). Therefore, current soil water status such as field capacity and wilting point as well as the dynamics of soil moisture content should be taken into account in order to assess the release and bioavailability of trace metals from certain soil types.

Organic amendments have been utilized as fertilizer and considered as a cost-effective approach to immobilize the bioavailable trace metal fraction and mitigate the negative consequences associated with trace metals in contaminated soils (Almaroai et al. 2014; Herath et al. 2015; Rizwan et al. 2017). In this regard, compost and biochar are known to be agents with high potential to adsorb trace metals (Almaroai et al. 2014). Compost is a biologically stable organic compound produced from biological oxidation and humification of raw organic matter which are mostly the waste products from agriculture or food industry (Bernal et al. 2007). Many studies have recognized the capacity of compost as an amendment for remediation of trace metal contaminated sites (Kargar et al. 2015; Liang et al. 2017). It is also considered as a nutrient rich organic fertilizer that can be effectively used to improve soil quality and microbial activities (Larney and Angers 2012; Mackie et al. 2015; Cerdeira-Pérez et al. 2019).

Characteristics of serpentine soil are distinct (e.g., high $\mathrm{Mg}$ :Ca ratio) from any other soils anthropogenically contaminated with trace metals (Rajakaruna and Boyd 2014). 
Although the soil water status influences bioavailability of metals, not many studies have focused on the influence of soil moisture on trace metal availability in serpentine soils (Angle et al. 2003; Aziz et al. 2015; Tashakor et al. 2017). This is particularly significant as serpentine soils are being increasingly used for cultivation (Fernandez et al. 1999; Kanellopoulos et al. 2015; Nkrumah et al. 2019; CerdeiraPérez et al. 2019). As the incorporation of organic amendments under different soil moisture regimes may induce differential trace metal release, this study investigated the influence of soil water status on the bioavailability of trace metals in serpentine soil and evaluated the effects of different bioamendments on immobilization/release of trace metals, including on the germination and vigor of seedlings.

\section{Materials and methods}

\subsection{Study site and sample collection}

Serpentine soil used for the study was obtained from Ussangoda serpentine outcrop (latitude $6^{\circ} 05^{\prime} 54^{\prime \prime} \mathrm{N}$ and longitude $80^{\circ} 59^{\prime} 11^{\prime \prime}$ E) located in the Southern part of Sri Lanka (see Fig. 1 in Vithanage et al. (2014)). Soil sample collection was done at several random locations and mixed together to acquire a homogenized composite sample weighing approximately $20 \mathrm{~kg}$. This composite soil sample was used for all experiments.

\subsection{Incubation experiment}

Soil treatments consisted of the following: (1) control (serpentine soil only), (2) soil $+2.5 \%$ dendro-biochar (Gliricidia sepium) (BC), (3) soil $+2.5 \% \mathrm{BC}+1.0 \%$ municipal solid waste compost $(\mathrm{CM})$, (4) soil $+2.5 \% \mathrm{BC}+2.5 \% \mathrm{CM}$, and (5) soil $+2.5 \% \mathrm{BC}+5.0 \% \mathrm{CM}$. The samples within each treatment were incubated under two different soil water status; saturated point (SP) and field capacity (FC) to evaluate the influence of soil water content and different amendments/ amendment ratios on the metal release from serpentine soils. All incubation tests were done in plastic containers, and each treatment was maintained in triplicate. For each treatment, $450 \mathrm{~g}$ of serpentine soils was used and compacted to achieve $1.48 \mathrm{~g} \mathrm{~cm}^{-3}$ of bulk density. Consequently, for each treatment, deionized water was added until SP. Containers having SP samples were air tightened by covering them with polyethylene and parafilm. The FC samples in porous containers were allowed to drain excess water for 3 days until no more water leached out, thus, reaching field capacity. Afterwards, containers having FC samples were also air tightened as mentioned earlier for SP samples. After 10 days of incubation, subsamples were taken from each soil sample to perform further experiments. Soil solution of each treatment was then eluded under $1 \mathrm{~atm}$ of pressure. A fraction of the subsamples from each treatment pot was separated for further chemical analysis. Subsequently, after pore water extraction, the incubation of remaining SP and FC soil samples was extended for 10 more days at permanent wilting point (PW), and after completion of incubation, subsamples were taken to carry out further experiments.

\subsection{Diethylenetriaminepentaacetic acid extraction}

The extraction of the bioavailable fraction of trace metals was performed using diethylenetriaminepentaacetic acid (DTPA) extraction method as described in Lindsay and Norvell (1978). Twenty milliliters of $0.005 \mathrm{M}$ DTPA, $0.01 \mathrm{M} \mathrm{CaCl}_{2}$, and $0.1 \mathrm{M}$ triethanolamine solution was poured into $10 \mathrm{~g}$ of each air-dried subsample of SP, FC, and PW treatments and shaken for $2 \mathrm{~h}$ at $100 \mathrm{rpm}$. Resulting solutions were centrifuged at $2000 \mathrm{rpm}$ for $15 \mathrm{~min}$ and filtered through $0.45 \mu \mathrm{m}$ filter paper. Filtrates were analyzed for $\mathrm{Ni}, \mathrm{Mn}, \mathrm{Co}$, and $\mathrm{Cr}$ using atomic absorption spectroscopy (AAS) (Shimadzu AA7000; Japan).

\subsection{Ammonium acetate extraction}

Cation exchange capacity (CEC) of each treatment was evaluated using the ammonium acetate extraction procedure (Anderson and Ingram 1993). Two grams of air-dried soil samples from each treatment was transferred into separate plastic tubes, and $20 \mathrm{ml}$ of ammonium acetate solution was added. After shaking at $100 \mathrm{rpm}$ for $15 \mathrm{~min}$, centrifugation was performed at $2000 \mathrm{rpm}$ for $15 \mathrm{~min}$, and supernatants were filtered through $0.45-\mu \mathrm{m}$ syringe filters. Filtrate was analyzed by AAS for $\mathrm{Na}, \mathrm{K}, \mathrm{Ca}$, and $\mathrm{Mg}$, and $\mathrm{CEC}$ of each treatment was calculated using the obtained data.

\subsection{Total organic carbon, soil available phosphate, and nitrate}

Nutrient contents (i.e., total organic carbon, available P, and N) of each SP, FC, and PW treatment we evaluated using the standard colorimetric methods described in Anderson and Ingram (1993).

\subsection{Leachate analysis}

Leachates that eluded from each treatment of SP and FC soils were filtered through $0.45 \mu \mathrm{m}$ syringe filters and analyzed using AAS for $\mathrm{Ni}, \mathrm{Mn}, \mathrm{Co}$, and $\mathrm{Cr}$.

\subsection{Seed germination experiment}

Seed germination study was carried out to evaluate the synergistic effect of soil water status and different amendments/ 
amendment ratios on germination performance of two mostly cultivated species in Sri Lanka, namely, Mung bean (Vigna radiata) and Tomato (Solanum lycopersicum). Twenty grams of serpentine soils in separate petri dishes was incubated for 7 days with five different amendment ratios used in the previous study (i.e., (1) control (serpentine soil only), (2) soil + $2.5 \% \mathrm{BC}$, (3) soil $+2.5 \% \mathrm{BC}+1.0 \% \mathrm{CM}$, (4) soil $+2.5 \% \mathrm{BC}$ $+2.5 \% \mathrm{CM}$, and (5) soil $+2.5 \% \mathrm{BC}+5.0 \% \mathrm{CM}$ ) with respective soil water status of SP, FC, and PW. Each treatment was run as triplicates. After the incubation period, each petri dish was divided into equal parts, and five seeds each of mung bean and tomato were placed separately in each area. Seeds were allowed to germinate under ambient atmospheric conditions. The germination percentage of seeds in each setup was recorded at $24 \mathrm{~h}$ intervals for 5 days. Seeds were considered as germinated when the radicle emerged. After 5 days of germination, the length of each seedling was measured, and the germination index, the time for $50 \%$ germination, and the seedling vigor index were calculated.

\subsubsection{Germination index}

Germinations index (GI) for each seed type was calculated using the equation below (Siddiqui and Al-Whaibi 2014).

$G I=\sum G t / D t$

where $G t$ is germination percentage of seeds and $D t$ is number of days taken by seeds to germinate.

\subsubsection{Seedling vigor index}

Seedling vigor index (SVI) was calculated according to Vashisth and Nagarajan (2010).

$S V I=$ germination percentage

$\times$ mean value of seedling length

\subsection{Statistical analysis}

All statistical analyses were carried out using the statistical software package MINITAB ${ }^{\circledR}$ 16.1.0. Bioavailable trace metals (viz. $\mathrm{Ni}, \mathrm{Mn}, \mathrm{Co}$, and $\mathrm{Cr}$ ), soil nutrients (viz. $\mathrm{NO}_{3}{ }^{-}$, $\mathrm{PO}_{4}{ }^{3-}$, and \% TOC), CEC, seed germination index, and seedling vigor index among five different amendment ratios under different soil water status were compared performing one-way ANOVA. Additionally, for each measured variable, Tukey pairwise comparisons were performed among five amendment ratios.

\section{Results}

Table 1 highlights the DTPA extractable trace metal concentration of Ussangoda serpentine soils. The respective percentage values for bioavailable $\mathrm{Ni}, \mathrm{Mn}, \mathrm{Cr}$, and $\mathrm{Co}$ of the total concentrations of metals mentioned in the previous study of Rajapaksha et al. (2012) are 2.007, 7.581, 0.005, and 5.900\%. The serpentine soil examined contained comparatively low concentrations of $\mathrm{NO}_{3}{ }^{-}$and $\mathrm{PO}_{4}{ }^{3-}$ which are considered as available forms of nitrogen and phosphorus for the plants. Similarly, low values for percentage total organic carbon (\%TOC) and cation exchange capacity (CEC) were reported for the serpentine soils (Table 1).

Figure 1 illustrates the influence of soil water content on bioavailability of trace metals: $\mathrm{Ni}, \mathrm{Mn}, \mathrm{Cr}$, and Co. The highest bioavailable concentrations of $\mathrm{Ni}$ and $\mathrm{Mn}$ (133.72 and $0.95 \mathrm{mg} \mathrm{kg}^{-1}$, respectively) were reported in SP-PW. However, the lowest concentrations were observed at $\mathrm{FC}$ for $\mathrm{Ni}\left(121.39 \mathrm{mg} \mathrm{kg}^{-1}\right)$ and SP for $\mathrm{Cr}\left(0.20 \mathrm{mg} \mathrm{kg}^{-1}\right)$. In contrast, the highest bioavailability of Mn and Co was found at SP (71.40 and $5.90 \mathrm{mg} \mathrm{kg}^{-1}$, respectively) and the lowest bioavailable concentration was reported at SP-PW (45.91 and $4.05 \mathrm{mg} \mathrm{kg}^{-1}$, respectively).

Application of organic amendment at all four ratios significantly reduced (one-way ANOVA, $p<0.0001$ at $\alpha=0.05$ ) the bioavailable concentration of all four examined trace metals under all four soil water contents (Fig. 2). The maximum bioavailable concentration of Ni was observed at SP-PW with no amendment (control) (133.72 $\mathrm{mg} \mathrm{kg}^{-1}$ ) and the lowest was present at FC-PW with the highest amendment ratio (43.32 $\mathrm{mg} \mathrm{kg}^{-1}$ ). The reduction of bioavilable Ni concentration in FC-PW soil at the maximum amendment ratio is $67.6 \%$ compared with its control. However, considering the overall results, $2.5 \% \mathrm{BC}+2.5 \% \mathrm{CM}$ and $2.5 \% \mathrm{BC}+5.0 \% \mathrm{CM}$ were equally effective for immobilization of bioavailable $\mathrm{Ni}$ from serpentine soil.

The control set at SP contained significantly higher (oneway ANOVA, $p<0.050$ at $\alpha=0.05)$ bioavailable concentration of Mn (71.40 $\mathrm{mg} \mathrm{kg}^{-1}$ ) (Fig. 2). The minimum value for bioavailable $\mathrm{Mn}$ concentration was reported from FC-PW treated with $2.5 \% \mathrm{BC}+1.0 \% \mathrm{CM}$ amendment ratio (5.64 $\left.\mathrm{mg} \mathrm{kg}^{-1}\right)$, which is a $92.1 \%$ reduction from the control treatment of FC-PW. However, statistical analyses revealed that the SP-PW and FC-PW with all amendment ratios (i.e., $2.5 \% \mathrm{BC}+0.0-5.0 \% \mathrm{CM}$ ) exhibited no significant difference (one-way ANOVA, $p>0.050$ at $\alpha=0.05$ ) and all were found equally effective for immobilization of $\mathrm{Mn}$ in the serpentine soil.

The highest DTPA extractable Co concentration was reported in the control set (with no amendment) at SP $\left(5.88 \mathrm{mg} \mathrm{kg}^{-1}\right)$. However, it was not significantly different (one-way ANOVA, $p>0.050$ at $\alpha=0.05$ ) from the control at FC (5.42 $\left.\mathrm{mg} \mathrm{kg}^{-1}\right)$. Similar to $\mathrm{Mn}$, the lowest concentration 


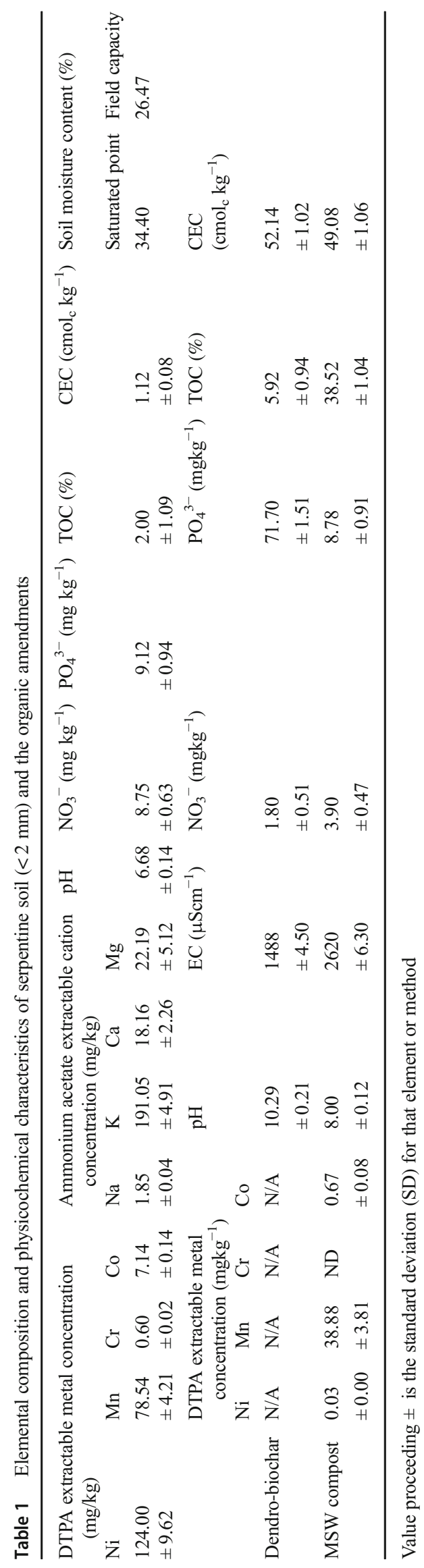

of bioavailable Co was observed from the treatment at FC-PW amended with $2.5 \% \mathrm{BC}+1.0 \% \mathrm{CM}\left(0.18 \mathrm{mg} \mathrm{kg}^{-1}\right)$, a $96.9 \%$ reduction from the control set at FC-PW.

As shown in Fig. 2, Cr exhibits the lowest bioavailability compared with the other three trace metals. The highest bioavailability of $\mathrm{Cr}$ was found at SP-PW with no amendments $\left(0.95 \mathrm{mg} \mathrm{kg}^{-1}\right)$. However, it is not significantly different (oneway ANOVA, $p>0.050$ at $\alpha=0.05$ ) from the control at FC$\mathrm{PW}$. Interestingly, the SP soils incubated with any amendment ratio (i.e., $2.5 \% \mathrm{BC}+0.0-5.0 \% \mathrm{CM}$ ) were able to completely immobilize $\mathrm{Cr}$.

The soil solution eluded from each SP and FC treatments after 10 days of incubation contained extremely low concentrations of $\mathrm{Ni}$ and $\mathrm{Mn}$ compared with their bioavailable concentrations (Table 2). Moreover, the Ni concentration of both SP and FC solutions decreased with the addition of amendments. The FC soils showed continuous reduction of Ni concentration until $\mathrm{FC} 4(2.5 \% \mathrm{BC}+2.5 \% \mathrm{CM})$ and became constant afterwards. However, the lowest Ni concentration was reported in SP $3(2.5 \% \mathrm{BC}+1.0 \% \mathrm{CM})$ and increased slightly with the increasing amendment ratio. In contrast to $\mathrm{Ni}$, soil solution from SP 1 (control) contained lowest Mn concentration, and the concentration increased with an increasing amendment ratio. Besides, in FC soils, the highest concentration of $\mathrm{Mn}$ was observed in FC 1 (control) while minimum concentration was found in $\mathrm{FC} 3(2.5 \% \mathrm{BC}+1.0 \% \mathrm{CM})$ and increased subsequently. Moreover, the $\mathrm{Mn}$ concentrations in soil solutions from FC soils were lower than those in extracted soil solution from SP soils, except SP 1. Furthermore, the Co and $\mathrm{Cr}$ were not present in either of the extracted soil solutions.

With the addition of organic amendments, dendro-biochar (BC) and municipal solid waste compost (CM), soil nutrient content and examined soil chemical parameters increased drastically (Fig. 3). The highest amendment ratio resulted in the highest (one-way ANOVA, $p<0.050$ at $\alpha=0.05$ ) nutrient content of treated serpentine soil except FC and SP-PW treatments which did not exhibit significant difference among amendment ratios of $2.5 \% \mathrm{BC}, 2.5 \% \mathrm{BC}+2.5 \% \mathrm{CM}$, and $2.5 \% \mathrm{BC}+5.0 \% \mathrm{CM}$ (one-way ANOVA, $p>0.05$ at $\alpha=$ 0.05). However, the maximum amendment ratio in FC-PW soil contained the highest concentration $\left(32.49 \mathrm{mg} \mathrm{kg}^{-1}\right)$ of $\mathrm{NO}_{3}{ }^{-}$among all the treatments, and it was $271.3 \%$ higher than in the untreated serpentine soil. In contrast to the $\mathrm{NO}_{3}{ }^{-}$, the highest $\mathrm{PO}_{4}{ }^{3-}$ concentration was observed in SP-PW soil with the uppermost amendment ratio $\left(15.48 \mathrm{mg} \mathrm{kg}^{-1}\right)$, which is $69.7 \%$ higher compared with untreated serpentine soils. Moreover, the overall results show that the conditions provided by SP-PW water status are more favorable for high $\mathrm{PO}_{4}{ }^{3-}$ concentration than the other three soil water status (Fig. 3).

As expected, \% TOC of treated soils increased with the increasing amendment ratio (Fig. 3). However, FC-PW with maximum amendment ratio contained the highest amount of 

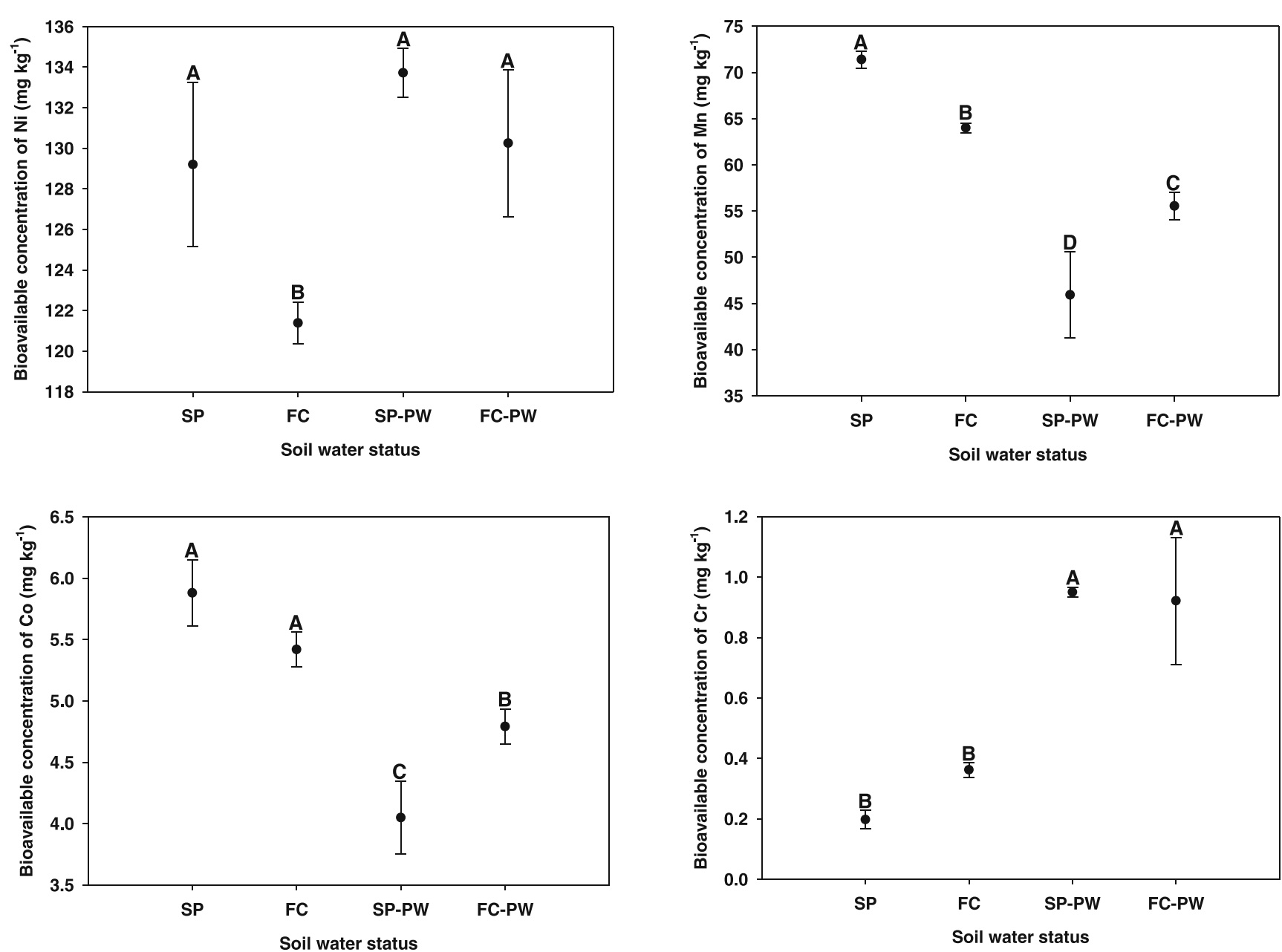

Fig. 1 Concentrations of bioavailable trace metals of $\mathrm{Ni}, \mathrm{Mn}, \mathrm{Co}$, and $\mathrm{Cr}$ in untreated serpentine soil under different soil water contents. Letters are assigned from the pairwise comparison performed using Tukey method.

\% TOC (3.2\%), which is $58.0 \%$ higher than in the untreated serpentine soils. Moreover, some of the treatments such as $2.5 \% \mathrm{BC}+2.5 \% \mathrm{CM}$ amendment ratios of SP-PW and FCPW soil water status contributed to reduced \% TOC than that of their consecutively low amendment ratio.

Furthermore, all of the treated serpentine soil samples with organic amendments clearly showed increased CEC values compared with the untreated serpentine soil (Fig. 3). The highest CEC value was reported for SP soil with the highest amendment ratio $\left(8.29 \mathrm{cmol}_{\mathrm{c}} \mathrm{kg}^{-1}\right)$ while the lowest CEC value was observed in FC treatment with no amendment $\left(1.65 \mathrm{cmol}_{\mathrm{c}} \mathrm{kg}^{-1}\right)$. For instance, the highest CEC value of SP treatment indicated $640.5 \%$ of increment over the untreated serpentine soil.

The mung beans and tomato seeds germinated in both SP and FC soil while no seed germination was observed in the soil incubated at WP (Table S1 - Electronic Supplementary Material). All the mung beans in soils incubated at FC soil water status germinated regardless of the amendment ratio. Therefore, the germination index (GI) for mung seed that

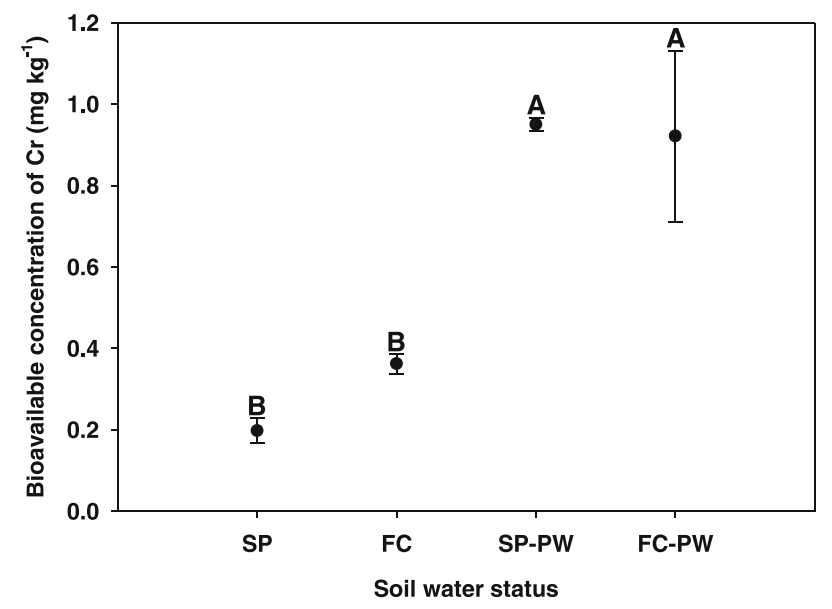

(SP, incubated at saturated point; FC, incubated at field capacity; SP-PW, incubated at saturated point followed by permanent wilting point; and FC-PW, incubated at field capacity followed by permanent wilting point)

germinated at $\mathrm{FC}$ exhibited no variation since all values are identical (Fig. 4). Also, the GI among mung beans germinated with different amendment ratios under SP soil water status did not show any significant difference (one-way ANOVA, $p=0.452$ at $\alpha=0.05$ ). Although, the germination of tomato seeds showed differences between SP and FC soil water status and among amendment ratios, there wass no significant difference (one-way ANOVA, $p>0.050$ at $\alpha=0.05$ ) for GI (Fig. 4).

Figure 5 shows the variation of seedling vigor index (SVI) among mung bean and tomato seedlings which were grown in SP and FC soils with different amendment ratios. Although GI did not reflect a significant difference for the germination of mung bean between SP and FC treatments, SVI indicated a significant difference (one-way ANOVA, $p<0.0001$ at $\alpha=$ 0.05 ) for the vigor of mung bean seedlings among SP and FC. Conversely, different amendment ratios within SP and FC treatments did not show significant effect on the vigor of mung bean seedlings (one-way ANOVA, $p=0.430$ and $p=$ 0.111 at $\alpha=0.05$ for SP and FC, respectively). In contrast, 

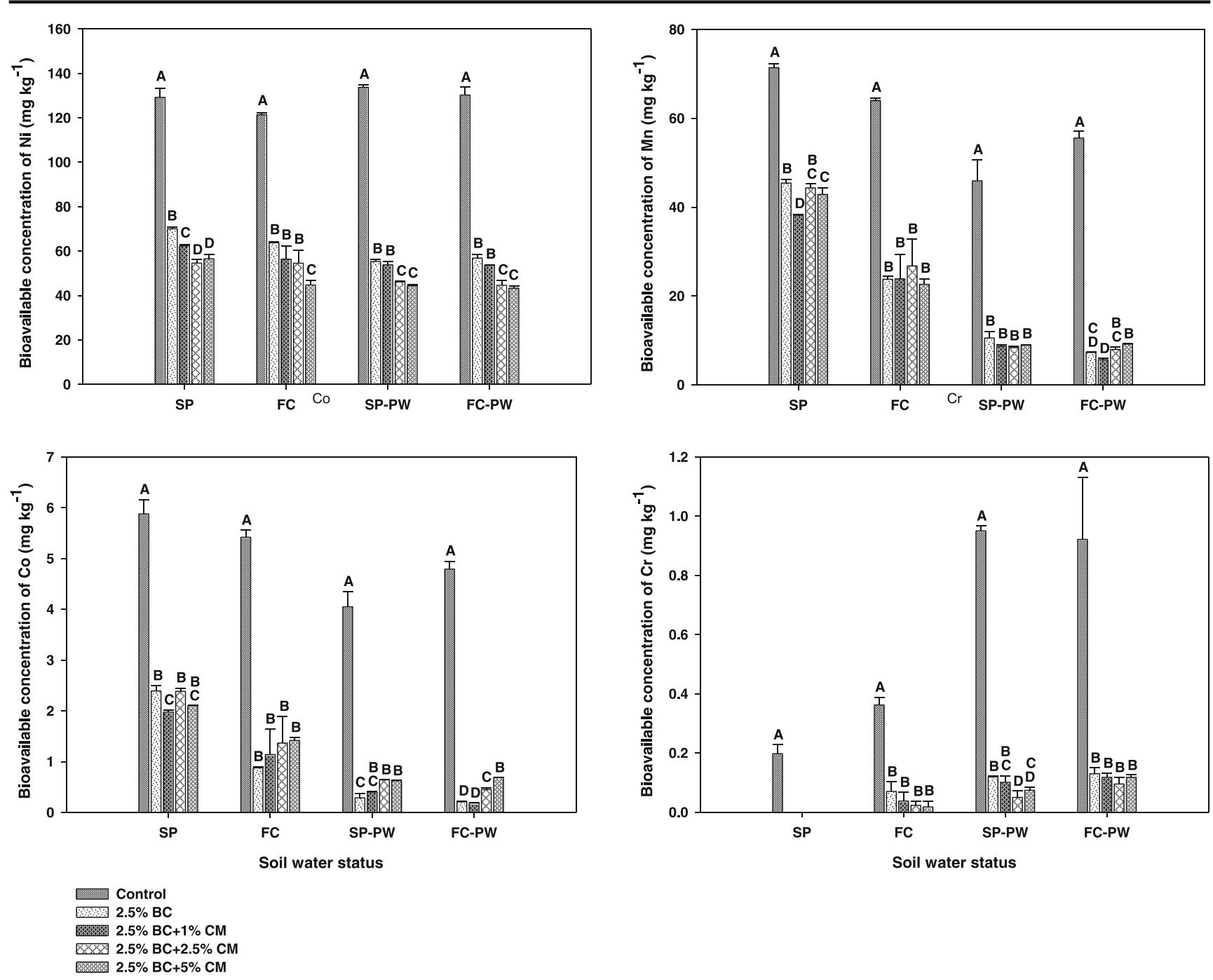

Fig. 2 Bioavailable trace metal concentrations at different amendment ratios under different soil water status. Letters are assigned from the pairwise comparison performed for five treatments under different soil water levels using Tukey method. (SP, incubated at saturated point; FC,

SVI of tomato reflected no difference for SP and FC treatments (one-way ANOVA, $p=0.258$ at $\alpha=0.05$ ). Furthermore, different amendment ratios of SP had significant influence (one-way ANOVA, $p=0.020$ at $\alpha=0.05$ ) on the SVI of tomato while different ratios of amendment used for

incubated at field capacity; SP-PW, incubated at saturated point followed by permanent wilting point; and FC-PW, incubated at field capacity followed by permanent wilting point)

FC did not exhibit a significant difference (one-way ANOVA, $p=0.063$ at $\alpha=0.05$ ) on the vigor of tomato seedlings. Therefore, water status of serpentine soil is an important determinant for the vigor of mung bean seedlings on serpentine soils, however, not for that of tomato seedlings.

Table 2 Trace metal concentration in soil solution eluded from SP and FC soils

\begin{tabular}{lcccccccrrrr}
\hline Soil solution & & SP1 & SP2 & SP3 & SP4 & SP5 & FC1 & FC2 & FC3 & FC4 & FC5 \\
\hline Metal concentration (mg kg & Ni & 0.87 & 0.23 & 0.21 & 0.26 & 0.32 & 0.94 & 0.59 & 0.41 & 0.28 & 0.28 \\
& & \pm 0.03 & \pm 0.02 & \pm 0.02 & \pm 0.01 & \pm 0.05 & \pm 0.03 & \pm 0.01 & \pm 0.04 & \pm 0.01 & \pm 0.01 \\
& Mn & 0.08 & 0.59 & 0.67 & 1.12 & 0.88 & 0.94 & 0.34 & 0.25 & 0.41 & 0.40 \\
& & \pm 0.01 & \pm 0.01 & \pm 0.02 & \pm 0.04 & \pm 0.01 & \pm 0.02 & \pm 0.02 & \pm 0.01 & \pm 0.01 & \pm 0.03 \\
\hline
\end{tabular}

SP and FC indicate two soil water status saturated point and field capacity while no. 1-5 represent ratio of organic amendment

Values indicated are average of three determinations and the values proceeding \pm is the standard deviation (SD)

* $\mathrm{Co}$ and $\mathrm{Cr}$ are not detected in any of the soil solutions eluded 

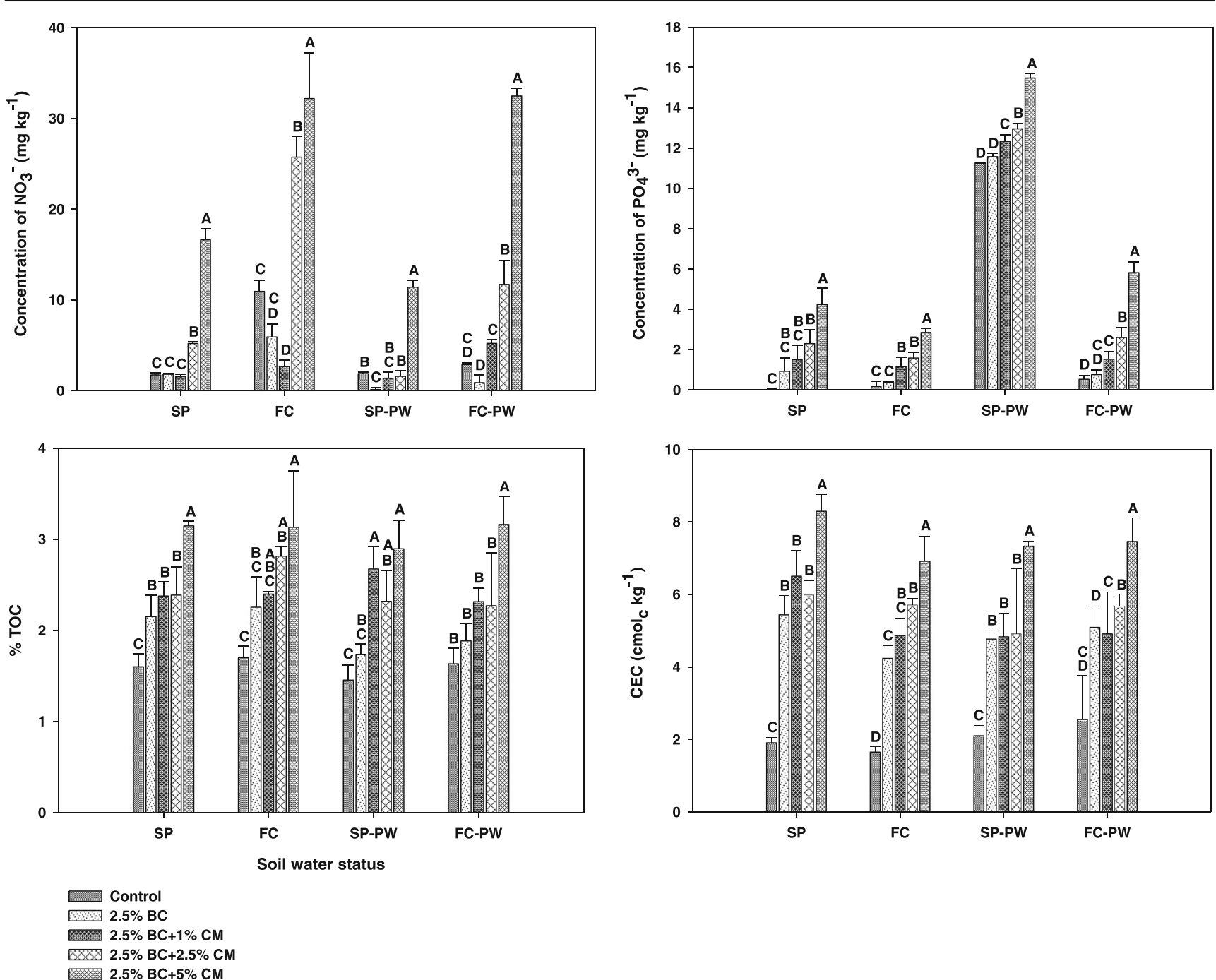

Fig. 3 Changes in the concentration of nitrate $\left(\mathrm{NO}_{3}{ }^{-}\right)$, phosphate $\left(\mathrm{PO}_{4}{ }^{3-}\right)$, total organic carbon (\%TOC), and cation exchange capacity (CEC) at different amendments ratios under different soil water status. Letters are assigned from the pairwise comparison performed for five treatments under

\section{Discussion}

The bioavailable concentrations found for $\mathrm{Ni}, \mathrm{Mn}, \mathrm{Cr}$, and $\mathrm{Co}$ (Table 1) are comparatively lower when compared with the total trace metal concentrations reported by Rajapaksha et al. (2012) for the soils in the same geological region. Metal bioavailability is the factor that exclusively determines the magnitude of the risk generated by toxic heavy metals for the environment and for humans (van Gestel 2008). Therefore, the bioavailable metal concentration indicates more accurate information about environmental toxicity generated by toxic trace metals. As a fraction of the total metal content, bioavailable trace metal concentration is lower than total trace metal concentration of soil. The DTPA extraction procedure delivers reliable estimation of bioavailable trace metal concentration in soils (Peijnenburg et al. 2007). The bioavailable Ni, Mn, Cr, and Co in the DTPA extraction of Ussangoda serpentine soil

different soil water levels using Tukey method. (SP, incubated at saturated point; FC, incubated at field capacity; SP-PW, incubated at saturated point followed by permanent wilting point; and FC-PW, incubated at field capacity followed by permanent wilting point)

were $2.007,7.581,0.005$, and $5.900 \%$ of the total metal concentration, respectively. The findings of Kumarathilaka and Vithanage (2017) reflect a similar tendency as bioavailable $\mathrm{Ni}$ and $\mathrm{Mn}$ concentrations of serpentine soils were 0.30 and $0.25 \%$, respectively, of total concentrations. Moreover, 33 323 and $11-76 \mathrm{mg} \mathrm{kg}^{-1}$ of $\mathrm{Ni}$ and $\mathrm{Mn}$, respectively, were found as bioavailable fractions from four serpentine localities in Sri Lanka (Vithanage et al. 2014). Even though the bioavailable concentration is comparatively lower than the total trace metal concentration, long-term risks associated with their accumulation in food chains cannot be ignored.

Serpentine soils are often characterized as nutrient poor, especially with low amounts of N, P, K, and Ca (Kruckeberg 2002; Vithanage et al. 2014; Baumeister et al. 2015). However, the low $\mathrm{N}$ conditions are mostly applicable only to the serpentine localities with scarce vegetation (Alexander et al. 2007), such as the Ussangoda serpentine body 

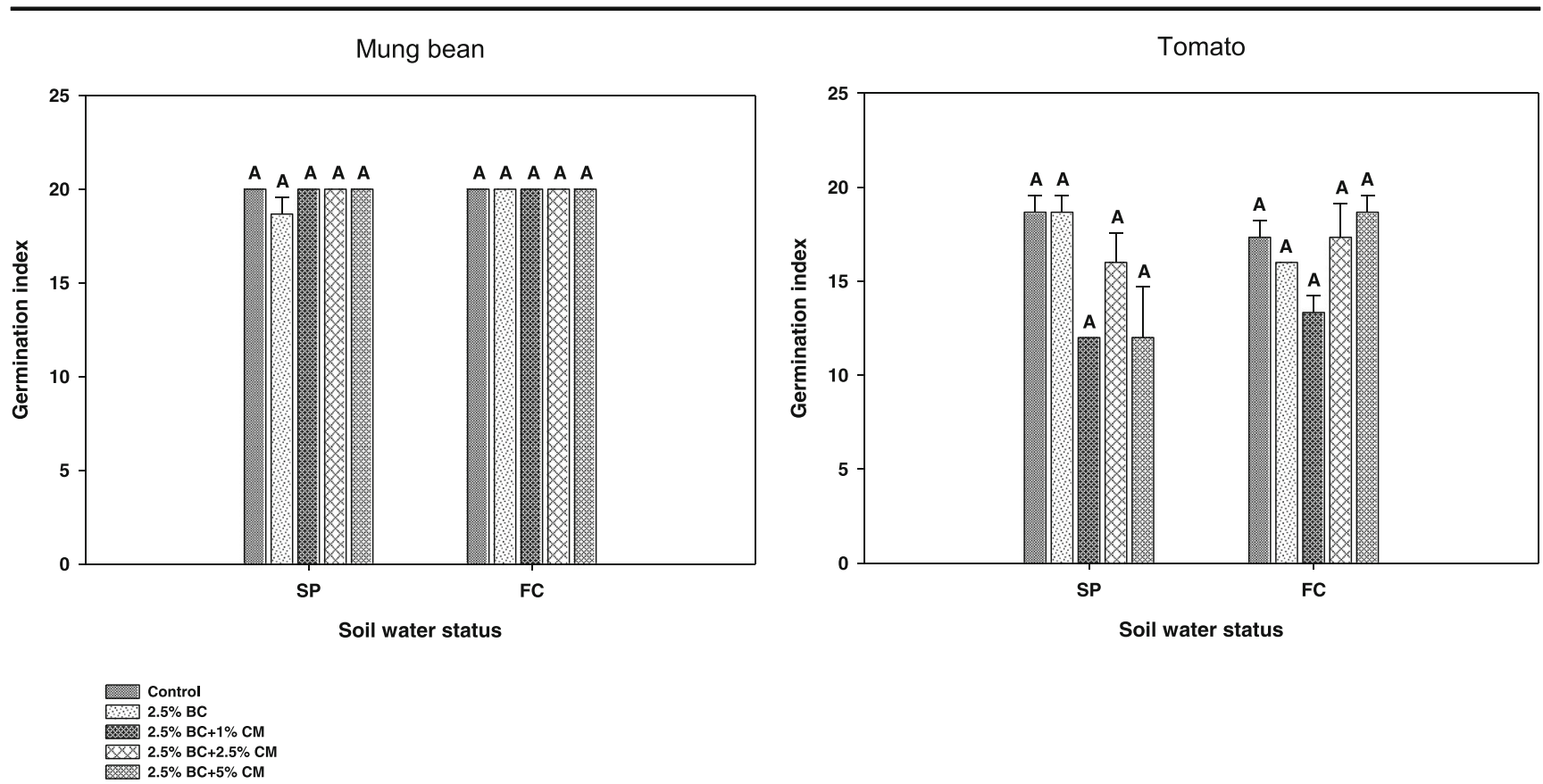

Fig. 4 Effects of soil water content and amendment ratio on germination index (GI) of mung bean and tomato. Letters are assigned from the pairwise comparison performed for five treatments under different soil

(Rajakaruna and Bohm 2002). Even though serpentine soils have elevated $\mathrm{Mg}$ levels, amounts of $\mathrm{Ca}, \mathrm{Na}$, and $\mathrm{K}$ are exceptionally low (Kumar and Maiti 2013). Therefore, low $\mathrm{Ca}, \mathrm{Na}$, and $\mathrm{K}$ concentrations ultimately contribute to low CEC values. Serpentine soils usually contain low organic matter content (Proctor and Woodell 1975; Seneviratne et al. 2015), typically attributed to poor

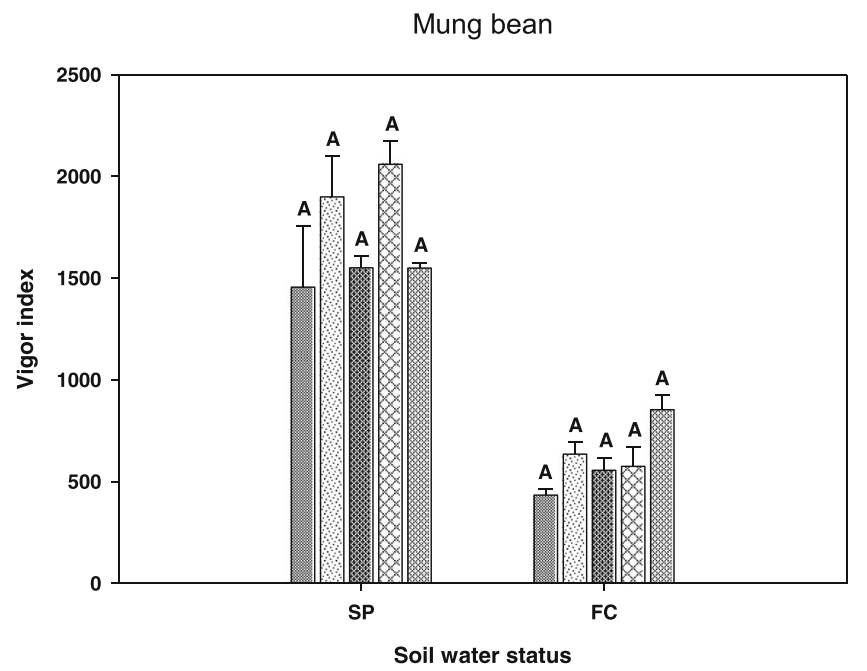

water levels using Tukey method. (SP, incubated at saturated point and FC, incubated at field capacity)

vegetation cover. Seneviratne et al. (2015) found 2.3\% total organic carbon in soil from Yudhaganawa serpentine deposit in Sri Lanka, which is similar to the findings of the present study. Moreover, the comparatively low soil water holding capacities observed at saturation point and field capacity are often reflected in serpentine soils worldwide (Schedlbauer 2015).
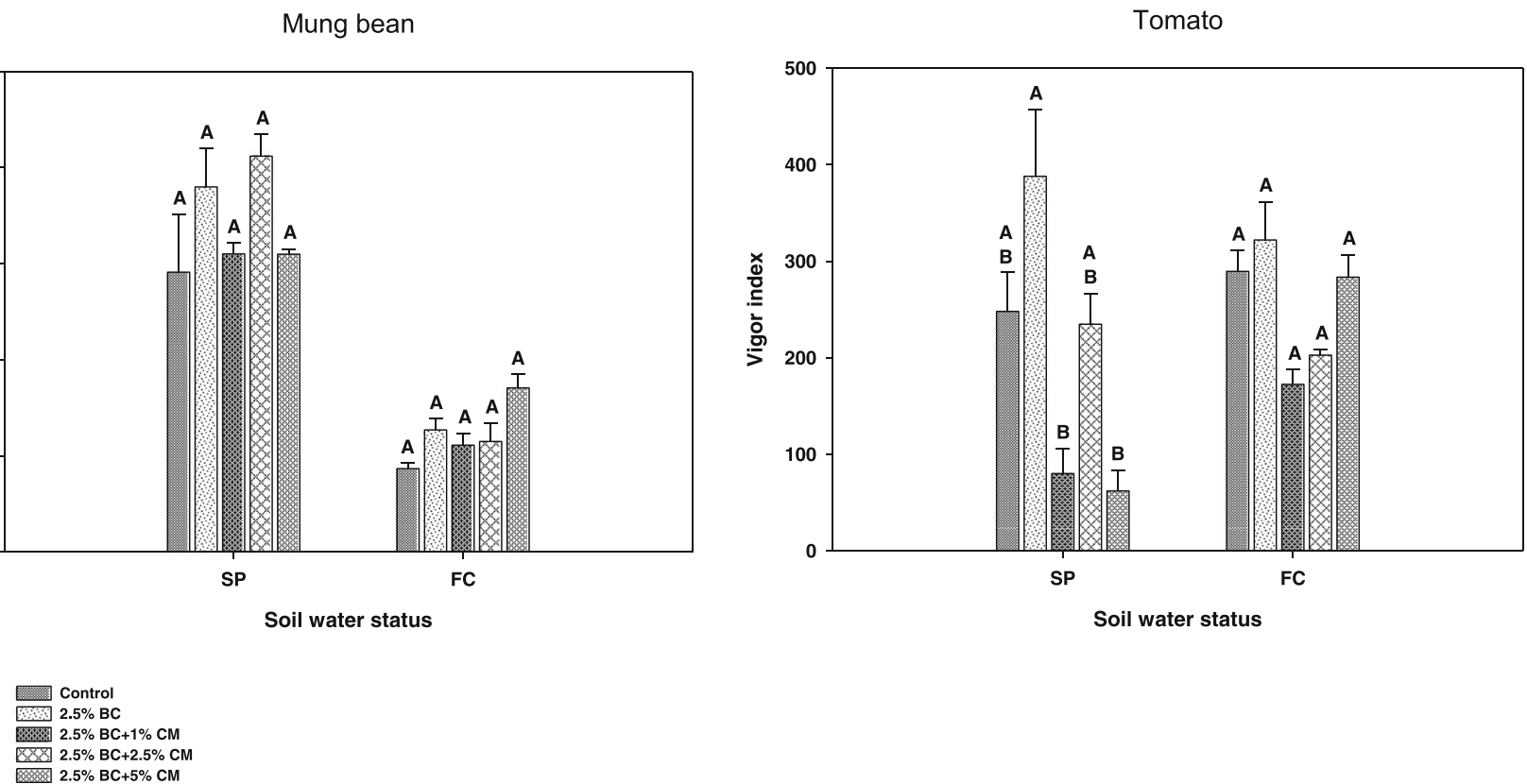

Fig. 5 Effects of soil water content and amendment ratio on seedling vigor index (SVI) on serpentine soils. Letters are assigned from the pairwise comparison performed for five treatments under different soil

water levels using Tukey method. (SP, incubated at saturated point and FC, incubated at field capacity) 
Soil moisture regime directly causes for changes in physicochemical and biological attributes of soil, including $\mathrm{pH}$, electrical conductivity, and organic matter content (Van den Berg and Loch 2000). Kashem and Singh (2004) list a number of changes which occur in soil under flooded conditions, including a decrease in redox potential (Eh) due to microbial respiration, increase in soil $\mathrm{pH}$, expansion of oxide surfaces, decrease in crystallinity, and the occurrence of hydrated forms of $\mathrm{Mn}$ and Fe. Changes of such physicochemical and biological factors influence the redistribution of trace metals among different fractions of soil as well as the dissolution of trace metals (Du Laing et al. 2007; Zheng and Zhang 2011; Liang et al. 2017). In the present study, the soil solutions eluded form serpentine soils incubated at saturated point (SP) and field capacity (FC) for 10 days contained lower concentrations of $\mathrm{Ni}$ and $\mathrm{Mn}$ compared with their bioavailable concentrations. $\mathrm{Co}$ and $\mathrm{Cr}$ were not detected in any of the extracted soil solutions. It is hypothesized that $\mathrm{Ni}$ is more liable to release in oxygen-rich conditions associated with dissolution of calcium carbonate (Du Laing et al. 2007). But our results do not reflect a pronounced increment in $\mathrm{Ni}$ concentration in water extracted from FC incubation compared with SP. In order to detect substantially high $\mathrm{Ni}$ concentrations in pore water of FC incubation, it may be necessary to have a considerably long period of time, as the dissolution of calcium carbonate is a slow process governed by weak acidity. Gambrell (1994) suggested that submerged conditions increase the Mn concentration in pore water as a result of microbial reduction of manganese oxides. Our study indicated contradictory results with slightly high concentration of $\mathrm{Mn}$ in FC soil solution than that of SP. However, metal dissolution under a reduced environment generated by microbial respiration and subsequent distribution into more stable fractions of soil is a two way process (Han and Banin 1997; Kashem and Singh 2004). Therefore, released Mn under saturated conditions can transform into more stable fractions of soil, leading to a reduction of Mn concentration in the soil solution. Moreover, the comparatively high concentration of $\mathrm{Mn}\left(38.88 \mathrm{mg} \mathrm{kg}^{-1}\right)$ present in municipal solid waste compost (CM) might have contributed to the increase of Mn concentration in soil solution with increasing amendment ratio, by dissolving under excess water content present in the saturated point (SP) soils. This is due to the high water content in SP soils which facilitates relatively high dissolution of Mn from soil and CM amendments. However, the bioavailable concentrations of $\mathrm{Co}$ and $\mathrm{Cr}$ content were comparatively much lower in serpentine soils (Table 1) and consequently were not detected in either SP or FC soil solutions.

The present study indicates the reduction of $\mathrm{Mn}$ and $\mathrm{Co}$ bioavailability under permanent wilting point $(\mathrm{PW})$ incubations of SP-PW and FC-PW than those of saturated point (SP) and field capacity (FC) incubations (Fig. 1). Under saturated soil conditions, trace metal release is induced by the reduction of FE and Mn oxides (Han and Banin 2000; Han et al. 2001). The reduction in bioavailable $\mathrm{Mn}$ and Co levels in SP-PW and FC-PW can be attributed to the inhibited microbial reduction by water deficient conditions under permanent wilting point and oxidation under oxic conditions. Conversely, $\mathrm{Cr}$ shows declined bioavailability in SP and FC incubations than subsequent incubations at permanent wilting point (SP-PW and FC-PW). Under low redox (reduced) conditions with $\mathrm{pH}$ ranging from 2 to $14, \mathrm{Cr}$ forms more stable species with less bioavailability (Avudainayagam et al. 2003). However, soil moisture content has less influence on the redistribution of $\mathrm{Cr}$ among different fractions of soil (Han et al. 2003). The bioavailability of Ni showed a significant reduction (one-way ANOVA, $p<0.0001$ at $\alpha=0.05$ ) in FC incubation than in the other three incubations. However, the bioavailable Ni concentrations in all four incubations ranged from 120 to $135 \mathrm{mg} \mathrm{kg}^{-1}$ which is closer to the bioavailable $\mathrm{Ni}$ concentration in un-incubated serpentine soil (124.04 mg kg-1, Table 1). The results of Fengxiang and Banin (1997) indicate that the transformation of Ni occurs from exchangeable and carbonate bound fractions to organic matter bound and easily reducible oxide fractions under flooded conditions. Similarly, field capacity conditions are also involved in the redistribution of $\mathrm{Ni}$ from exchangeable and carbonate bound fractions to an easily reducible fraction and organic matter bound fractions in a slow manner. Therefore, saturated conditions lead to a more pronounced distribution of $\mathrm{Ni}$ into more stable fractions than at field capacity. Similarly, Kashem and Singh (2004) found 47\% reduction of ammonium acetate $\left(1 \mathrm{M} \mathrm{NH}_{4} \mathrm{OAc}, \mathrm{pH} 7\right)$ extractable Ni in exchangeable fraction after submergence of contaminated soil for 24 weeks. However, 10 days of incubation might not be long enough for the initiation of transformation.

Biochar, a type of black carbon resulting from pyrolysis of biomass under no/limited oxygen conditions, has been proven to be an effective and low-cost organic amendment for trace metal-contaminated sites (Inyang et al. 2016). Previous research of our group has revealed strong immobilization capacity of $2.5 \%$ dendro-biochar (Gliricidia sepium biochar) on trace metals released from serpentine soils (Herath et al. 2015; Kumarathilaka and Vithanage 2017). Herath et al. (2015) found that dendro-biochar reduces bioavailable $\mathrm{Cr}$, $\mathrm{Ni}$, and $\mathrm{Mn}$ in serpentine soil by 96,36 , and $21 \%$, respectively. Similarly, compost generated from various feedstocks undergoing microbial oxidation under anaerobic conditions, is also a suitable amendment for trace metal-contaminated sites (Beesley et al. 2010; Karami et al. 2011). Compost amendment into contaminated soils can reduce bioavailability of trace metals by transformation to a more stable organic matter bound fraction (Manios et al. 2003; O'Dell et al. 2007). Therefore, our study focused primarily on the synergistic effects of different ratios of dendro-biochar (BC) and municipal solid waste compost $(\mathrm{CM})$ with different soil water regimes 
for determining the bioavailability of trace metals from serpentine soil.

In our study, all the amendment ratios, ranging from $\mathrm{BC}: \mathrm{CM}$ ratios of 2.5:0-5\%, were involved in a significant reduction (one-way ANOVA, $p<0.0001$ at $\alpha=0.05$ ) of the bioavailability of all four metals examined. Extensive surface area associated with microporous structure, polyaromatic nature, diverse surface functional groups, and high cation exchange capacity make biochar a good adsorbent for trace metals (Tang et al. 2012; Xu et al. 2014). Biochar application immobilizes and increases the stability of trace metals by complexation with surface functional groups, specific and non-specific adsorption, and ion exchange and precipitation (Zhang et al. 2013). In the current study, biochar alone leads to increased immobilization of Co under SPPW and FC-PW (Fig. 2). However, in most of the treatments, $\mathrm{BC}$ and $\mathrm{CM}$ together contribute to the maximum immobilization of bioavailable trace metals (Fig. 2). Liang et al. (2017) provide similar results to those of our study, showing that biochar-compost composites immobilize trace metals significantly more than the control. Combination of organic amendments is highly effective in reducing mobility of exchangeable trace metals in soils (Beesley et al. 2014). The humic substances and microorganisms in compost contribute to further oxidation of biochar surfaces, while biochar can also induce the humification of compost, providing favorable conditions for microbial growth (Wu et al. 2016; Wu et al. 2017). Organic matter also has the ability to interact with metals and contributes to their speciation, thereby reducing their mobility. Thus, high organic matter and microbial content in compost can induce high stability and low mobility of trace metals (Kalbitz and Wennrich 1998; Clemente et al. 2006). Further, the comparatively high $\mathrm{pH}$ of dendro-biochar ( $\mathrm{pH}$ 10.29) and municipal solid waste compost (pH 8.00) (Table 1) can synergistically increase the $\mathrm{pH}$ of serpentine soil which can then contribute to the stabilization of trace metals. Solubility of trace metals is strongly correlated with soil $\mathrm{pH}$, with high solubility and mobility occurring under low $\mathrm{pH}$ values (Huang et al. 2014; Zeng et al. 2011).

All the organic amendment ratios used under all the soil water status significantly (one-way ANOVA, $p<0.0001$ at $\alpha=0.05$ ) increased the concentration of soil $\mathrm{NO}_{3}{ }^{-}, \mathrm{PO}_{4}{ }^{3-}$, percent total organic carbon (\%TOC), and cation exchange capacity (CEC), compared with the control (Fig. 3). The application of biochar is known to improve various soil properties such as cation exchange capacity (CEC), soil total organic carbon (\%TOC), pH, and soil nutrient concentrations (Agegnehu et al. 2015; Zeng et al. 2015). However, the effects of biochar on soil nutrient content are dependent on the type of biomass used for biochar production (Gunarathne et al. 2017). Similarly, compost is a quality organic fertilizer which can provide soil nutrients as well as improve physicochemical and microbial properties of soil (Schulz et al. 2013; Mackie et al. 2015). Figure 3 shows a similar trend for CEC and \% TOC, as they increase with increasing amendment ratios and are not influenced by the soil water status.
The dendro-biochar and municipal solid waste compost used for this study consisted of 46.6- and 43.8-fold higher cation exchange capacity (CEC), respectively, than the CEC of serpentine soils (Table 1). The higher CEC values correspond to a higher number of cation exchange sites, indicating the capacity of the amendment to immobilize trace metals by ion exchange. Figure 3 shows the extensive increment of soil total organic carbon (\%TOC) levels with an increasing amendment ratio. The dendro-biochar and municipal solid waste compost consist of 2.9- and 19.3-fold higher \% TOC, respectively, compared with the serpentine soils (Table 1), contributing to an increase in $\%$ TOC in soil with an increasing organic amendment ratio. Increasing organic matter content has a pronounced effect on immobilization of trace metals as trace metals bind with surface functional groups of organic matter, making stable complexes. However, some of the treatments (i.e., $2.5 \% \mathrm{BC}+2.5 \% \mathrm{CM}$ amendment ratios of SP-PW and FC-PW soil water status) show a reduced \% TOC value under a consecutively low amendment ratio. This is usually attributed to the dissolution and removal of organic carbon particles with the soil solution and degradation by microbial activities.

The $\mathrm{NO}_{3}{ }^{-}$concentration in SP and SP-PW treatments shows a pronounced reduction compared with that of the FC and FCPW treatments (Fig. 3). The saturated condition has a significant impact on the loss of $\mathrm{NO}_{3}{ }^{-}$as ammonia. The study of Malhi et al. (1990) noted the extreme loss of $\mathrm{NO}_{3}{ }^{-}$from soil under flooded conditions. In our study, nearly twofold concentration of $\mathrm{NO}_{3}{ }^{-}$was lost by saturated conditions under the SP and SP-PW treatments. Furthermore, the $\mathrm{PO}_{4}{ }^{3-}$ concentration of SP-PW shows a pronounced increment than that in soil incubated under the other three soil water status. $\mathrm{PO}_{4}{ }^{3-}$-mineralizing bacteria, including genera Bacillus, Pseudomonas, and Rhizobium, play a critical role in the transformation of insoluble $\mathrm{PO}_{4}{ }^{3-}$ minerals into soluble forms (Rodríguez and Fraga 1999; Qian et al. 2019). Stimulation of $\mathrm{PO}_{4}{ }^{3-}$-mineralizing microbial growth under water logged conditions, followed by water deficient conditions, might be responsible for the elevated plant available $\mathrm{PO}_{4}{ }^{3}$ concentrations in SP-PW treatments.

The process of imbibition is involved in the absorption of water to seeds and the activation of enzymes essential for seed germination (Evans and Etherington 1990). The lack of plant available water under permanent wilting point (PW) inhibits the germination of seed, thereby acting as the critical factor for germination. However, there is no significant difference observed for the GI of mung bean and tomato seeds under either saturated point (SP) or field capacity (FC) (Fig. 4). Therefore, trace metal stress has no significant influence for the germination of either mung beans or tomato seeds. However, there was a significant difference observed in the SVI of mung beans between SP and FC (Fig. 5). The lower bioavailability of trace metals under water saturated conditions may have contributed to the significantly high SVI under SP than the SVI of mung beans grown under FC. 


\section{Conclusions}

All the amendment ratios significantly reduced the bioavailable trace metal concentrations we tested under all soil moisture regimes, compared with the respective control. The FC-PW treatment with the highest amendment ratio was significantly effective in reducing the bioavailable fraction of $\mathrm{Ni}(67.6 \%)$, while SP-PW and FC-PW with all amendment ratios ranging from $2.5 \% \mathrm{BC}$ to $0.0-5.0 \% \mathrm{CM}$ were equally effective against the removal of Mn (up to $92.1 \%$ ). The treatment of FC-PW amended with $2.5 \% \mathrm{BC}+1.0 \% \mathrm{CM}$ reduced the DTPA extractable Co by $96.9 \%$. Also, the SP soil water content under all amendment ratios (i.e., $2.5 \% \mathrm{BC}+0.0-5.0 \% \mathrm{CM}$ ) completely immobilized the bioavailable concentration of $\mathrm{Cr}$. The maximum amendment ratio in FC-PW soil was favorable for $\mathrm{NO}_{3}^{-}$while SP-PW soil with the highest amendment ratio was most effective at increasing the $\mathrm{PO}_{4}{ }^{3-}$ concentration. Moreover, FC-PW with the maximum amendment ratio contained the highest amount of \% TOC, and the maximum CEC value was reported from SP soil with the highest amendment ratio. Besides the amendment ratio, SP and FC influenced GI of mung bean and tomato seeds whereas there was no seed germination observed at PW. However, the SVI of mung bean seedlings exhibited a significant difference $(p<0.001)$ between SP and FC soil water status but no significant difference was detected among different amendment ratios. In contrast, no significant difference of SVI of tomato seedlings was observed $(p=0.258)$ at SP and FC, while a significant difference $(p=0.020)$ of SVI was detected among amendment ratios at SP. Overall, FC-PW soil water status effectively reduced the bioavailable concentrations of all four trace metals examined and increased the soil nutrient levels, including $\mathrm{NO}_{3}{ }^{-}$and \%TOC. Organic amendment ratios ranging from $2.5 \% \mathrm{BC}+$ $0.0-5.0 \% \mathrm{CM}$ effectively reduced the bioavailable fraction of all four trace metals while the highest amendment ratio contributed to the highest soil nutrient content. However, for seedling growth, soil water content was the limiting factor relative to the negative impact of toxic trace metals and the positive effect from increased soil nutrient content.

\section{References}

Agegnehu G, Bass AM, Nelson PN, Muirhead B, Wright G, Bird MI (2015) Biochar and biochar-compost as soil amendments: effects on peanut yield, soil properties and greenhouse gas emissions in tropical North Queensland, Australia. Agric Ecosyst Environ 213: 72-85

Alexander EB, Coleman RG, Harrison SP, Keeler-Wolfe T (2007) Serpentine geoecology of western North America: geology, soils, and vegetation. OUP, USA

Almaroai YA, Usman AR, Ahmad M, Moon DH, Cho J-S, Joo YK, Jeon C, Lee SS, Ok YS (2014) Effects of biochar, cow bone, and eggshell on $\mathrm{Pb}$ availability to maize in contaminated soil irrigated with saline water. Environ Earth Sci 71(3):1289-1296
Anderson JM, Ingram J (1993) Tropical soil biology and fertility, 2nd edt. A handbook of methods. CAB international, Wallingford

Angle JS, Baker AJ, Whiting SN, Chaney RL (2003) Soil moisture effects on uptake of metals by Thlaspi, Alyssum, and Berkheya. Plant Soil 256(2):325-332

Antibachi D, Kelepertzis E, Kelepertsis A (2012) Heavy metals in agricultural soils of the Mouriki-Thiva area (Central Greece) and environmental impact implications. Soil Sediment Contam 21(4):434 450

Avudainayagam S, Megharaj M, Owens G, Kookana RS, Chittleborough D, Naidu R (2003) Chemistry of chromium in soils with emphasis on tannery waste sites: a review. Rev Environ Contam Toxicol 178: 53-91

Aziz RA, Rahim SA, Sahid I, Idris WMR (2015) Speciation and availability of heavy metals on serpentinized paddy soil and paddy tissue. Procedia Soc Behav Sci 195:1658-1665

Baugé S, Lavkulich L, Schreier H (2013) Phosphorus and trace metals in serpentine-affected soils of the Sumas Basin, British Columbia. Can J Soil Sci 93(3):359-367

Baumeister JL, Hausrath EM, Olsen AA, Tschauner O, Adcock CT, Metcalf RV (2015) Biogeochemical weathering of serpentinites: an examination of incipient dissolution affecting serpentine soil formation. Appl Geochem 54:74-84

Beesley L, Moreno-Jiménez E, Gomez-Eyles JL (2010) Effects of biochar and greenwaste compost amendments on mobility, bioavailability and toxicity of inorganic and organic contaminants in a multi-element polluted soil. Environ Pollut 158(6):2282-2287

Beesley L, Inneh OS, Norton GJ, Moreno-Jimenez E, Pardo T, Clemente R, Dawson JJ (2014) Assessing the influence of compost and biochar amendments on the mobility and toxicity of metals and arsenic in a naturally contaminated mine soil. Environ Pollut 186:195-202

Bernal M, Clemente R, Walker D (2007) The role of organic amendments in the bioremediation of heavy metal-polluted soils. In: Gore RW (ed) Environmental research at the leading edge. Nova Science Publishers, Inc, New York

Brooks RR (1987) Serpentine and its vegetation: a multidisciplinary approach. Dioscorides Press, Portland

Cerdeira-Pérez A, Monterroso C, Rodríguez-Garrido B, Machinet G, Echevarria G, Prieto-Fernández Á, Kidd PS (2019) Implementing nickel phytomining in a serpentine quarry in NW Spain. J Geochem Explor 197:1-13

Cheng C-H, Jien S-H, Iizuka Y, Tsai H, Chang Y-H, Hseu Z-Y (2011) Pedogenic chromium and nickel partitioning in serpentine soils along a toposequence. Soil Sci Soc Am J 75(2):659-668

Clemente R, Escolar Á, Bernal MP (2006) Heavy metals fractionation and organic matter mineralisation in contaminated calcareous soil amended with organic materials. Bioresour Technol 97(15):18941901

Du Laing G, Vanthuyne D, Vandecasteele B, Tack F, Verloo M (2007) Influence of hydrological regime on pore water metal concentrations in a contaminated sediment-derived soil. Environ Pollut 147(3): $615-625$

Evans CE, Etherington JR (1990) The effect of soil water potential on seed germination of some British plants. New Phytol 115(3):539548

Fengxiang H, Banin A (1997) Long-term transformations and redistribution of potentially toxic heavy metals in arid-zone soils incubated: I. Under saturated conditions. Water Air Soil Pollut 95(1-4):399-423

Fernandez S, Seoane S, Merino A (1999) Plant heavy metal concentrations and soil biological properties in agricultural serpentine soils. Commun Soil Sci Plant Anal 30(13-14):1867-1884

Galey M, Van Der Ent A, Iqbal M, Rajakaruna N (2017) Ultramafic geoecology of south and Southeast Asia. Bot Stud 58(1):18

Gambrell R (1994) Trace and toxic metals in wetlands - a review. J Environ Qual 23(5):883-891 
Gray CW, Mclaren RG (2006) Soil factors affecting heavy metal solubility in some New Zealand soils. Water Air Soil Pollut 175(1-4):3-14

Gunarathne V, Mayakaduwa S, Vithanage M (2017) Biochar's influence as a soil amendment for essential plant nutrient uptake. In Essential Plant Nutrients, pp. 47-67. Springer, Cham

Han F, Banin A (1997) Long-term transformations and redistribution of potentially toxic heavy metals in arid-zone soils incubated: I. Under saturated conditions. Water Air Soil Pollut 95(1):399-423

Han F, Banin A (2000) Long-term transformations of Cd, Co, Cu, Ni, Zn, $\mathrm{V}, \mathrm{Mn}$ and $\mathrm{Fe}$ in the native arid-zone soils under saturated condition. Commun Soil Sci Plant Anal 31:943-957

Han F, Banin A, Triplett G (2001) Redistribution of heavy metals in aridzone soils under a wetting-drying cycle soil moisture regime. Soil Sci 166(1):18-28

Han F, Banin A, Kingery W, Triplett G, Zhou L, Zheng S, Ding W (2003) New approach to studies of heavy metal redistribution in soil. Adv Environ Res 8(1):113-120

Harrison SP, Kruckeberg AR (2008) Garden on the rocks. Nat Hist 117(4):40-44

Harrison S, Rajakaruna N (2011) Serpentine: the evolution and ecology of a model system. University of California Press, Berkeley, CA

Herath I, Kumarathilaka P, Navaratne A, Rajakaruna N, Vithanage M (2015) Immobilization and phytotoxicity reduction of heavy metals in serpentine soil using biochar. J Soils Sediments 15(1):126-138

Huang B, Li Z, Huang J, Guo L, Nie X, Wang Y, Zhang Y, Zeng G (2014) Adsorption characteristics of $\mathrm{Cu}$ and $\mathrm{Zn}$ onto various size fractions of aggregates from red paddy soil. J Hazard Mater 264:176-183

Inyang MI, Gao B, Yao Y, Xue Y, Zimmerman A, Mosa A, Pullammanappallil P, Ok YS, Cao X (2016) A review of biochar as a low-cost adsorbent for aqueous heavy metal removal. Crit Rev Environ Sci Technol 46(4):406-433

Kabala C, Singh BR (2001) Fractionation and mobility of copper, lead, and zinc in soil profiles in the vicinity of a copper smelter. J Environ Qual 30(2):485-492

Kalbitz K, Wennrich R (1998) Mobilization of heavy metals and arsenic in polluted wetland soils and its dependence on dissolved organic matter. Sci Total Environ 209(1):27-39

Kanellopoulos C, Argyraki A, Mitropoulos P (2015) Geochemistry of serpentine agricultural soil and associated groundwater chemistry and vegetation in the area of Atalanti, Greece. J Geochem Explor 158:22-33

Karami N, Clemente R, Moreno-Jiménez E, Lepp NW, Beesley L (2011) Efficiency of green waste compost and biochar soil amendments for reducing lead and copper mobility and uptake to ryegrass. J Hazard Mater 191(1-3):41-48

Kargar M, Clark OG, Hendershot WH, Jutras P, Prasher SO (2015) Immobilization of trace metals in contaminated urban soil amended with compost and biochar. Water Air Soil Pollut 226(6):191

Kashem M, Singh B (2004) Transformations in solid phase species of metals as affected by flooding and organic matter. Commun Soil Sci Plant Anal 35(9-10):1435-1456

Kierczak J, Neel C, Aleksander-Kwaterczak U, Helios-Rybicka E, Bril H, Puziewicz J (2008) Solid speciation and mobility of potentially toxic elements from natural and contaminated soils: a combined approach. Chemosphere 73(5):776-784

Kruckeberg AR (2002) Geology and plant life: the effects of landforms and rock types on plants. University of Washington Press, Seattle, WA

Kumar A, Maiti SK (2013) Availability of chromium, nickel and other associated heavy metals of ultramafic and serpentine soil/rock and in plants. Int J Adv Res Technol 3(2):256-268

Kumarathilaka P, Vithanage M (2017) Influence of Gliricidia sepium biochar on attenuate perchlorate-induced heavy metal release in serpentine soil. J Chem 2017: 1-8

Kumarathilaka P, Oze C, Vithanage M (2016) Perchlorate mobilization of metals in serpentine soils. Appl Geochem 74:203-209
Larney FJ, Angers DA (2012) The role of organic amendments in soil reclamation: a review. Can J Soil Sci 92(1):19-38

Lázaro JD, Kidd P, Martinez CM (2006) A phytogeochemical study of the Trás-os-Montes region (NE Portugal): possible species for plantbased soil remediation technologies. Sci Total Environ 354(2-3): 265-277

Liang J, Yang Z, Tang L, Zeng G, Yu M, Li X, Wu H, Qian Y, Li X, Luo $Y$ (2017) Changes in heavy metal mobility and availability from contaminated wetland soil remediated with combined biochar-compost. Chemosphere 181:281-288

Lindsay WL, Norvell WA (1978) Development of a DTPA soil test for zinc, iron, manganese, and copper. Soil Sci Soc Am J 42(3):421428

Mackie K, Marhan S, Ditterich F, Schmidt H, Kandeler E (2015) The effects of biochar and compost amendments on copper immobilization and soil microorganisms in a temperate vineyard. Agric Ecosyst Environ 201:58-69

Malhi S, Mcgill W, Nyborg M (1990) Nitrate losses in soils: effect of temperature, moisture and substrate concentration. Soil Biol Biochem 22(6):733-737

Manios T, Stentiford E, Millner P (2003) Removal of heavy metals from a metaliferous water solution by Typha latifolia plants and sewage sludge compost. Chemosphere 53(5):487-494

Neilson S, Rajakaruna N (2015) Phytoremediation of agricultural soils: using plants to clean metal-contaminated arable land. In: Phytoremediation: Management of Environmental Contaminants, pp. 159-168, Eds. A. A. Ansari, S. S. Gill, G. R. Lanza, and L. Newman. Springer International Publishing, Switzerland

Nkrumah PN, Tisserand R, Chaney RL, Baker AJ, Morel JL, Goudon R, Erskine PD, Echevarria G, Van Der Ent A (2019) The first tropical 'metal farm': some perspectives from field and pot experiments. J Geochem Explor 198:114-122

O'dell R, Silk W, Green P, Claassen V (2007) Compost amendment of $\mathrm{Cu}-\mathrm{Zn}$ minespoil reduces toxic bioavailable heavy metal concentrations and promotes establishment and biomass production of Bromus carinatus (Hook and Arn.). Environ Pollut 148(1):115-124

Peijnenburg WJ, Zablotskaja M, Vijver MG (2007) Monitoring metals in terrestrial environments within a bioavailability framework and a focus on soil extraction. Ecotoxicol Environ Saf 67(2):163-179

Proctor J, Woodell SR (1975) The ecology of serpentine soils. Adv Ecol Res 9: 255-366

Qian T, Yang Q, Jun DCF, Dong F, Zhou Y (2019) Transformation of phosphorus in sewage sludge biochar mediated by a phosphatesolubilizing microorganism. Chem Eng J 359:1573-1580

Rajakaruna N, Baker AJ (2004) Serpentine: a model habitat for botanical research in Sri Lanka. Ceylon J Sci 32:1-19

Rajakaruna N, Bohm BA (2002) Serpentine and its vegetation: a preliminary study from Sri Lanka. J Appl Bot 76(1/2):20-28

Rajakaruna N, Boyd RS (2014) Serpentine soils. In: Gibson D (ed) Oxford bibliographies in ecology. Oxford University Press, New York

Rajapaksha AU, Vithanage M, Oze C, Bandara W, Weerasooriya R (2012) Nickel and manganese release in serpentine soil from the Ussangoda Ultramafic Complex, Sri Lanka. Geoderma 189:1-9

Rizwan M, Ali S, Abbas F, Adrees M, Zia-Ur-Rehman M, Farid M, Gill RA, Ali B (2017) Role of organic and inorganic amendments in alleviating heavy metal stress in oil seed crops. In: Oil seed crops: yield and adaptations under environmental stress, pp 224-235, Eds. P. Ahmad. John Wiley \& Sons, Ltd

RodríGuez H, Fraga R (1999) Phosphate solubilizing bacteria and their role in plant growth promotion. Biotechnol Adv 17(4-5):319-339

Schedlbauer JL (2015) Serpentine ecosystem responses to varying water availability and prescribed fire in the US Mid-Atlantic region. Ecosphere 6(7):1-14 
Schulz H, Dunst G, Glaser B (2013) Positive effects of composted biochar on plant growth and soil fertility. Agron Sustain Dev 33(4): $817-827$

Seneviratne M, Seneviratne G, Madawala H, Iqbal M, Rajakaruna N, Bandara T, Vithanage M (2015) A preliminary study of the role of bacterial-fungal co-inoculation on heavy metal phytotoxicity in serpentine soil. Aust J Bot 63(4):261-268

Siddiqui MH, Al-Whaibi MH (2014) Role of nano-SiO2 in germination of tomato (Lycopersicum esculentum seeds Mill.). Saudi J Biol Sci 21(1):13-17

Tang W-W, Zeng G-M, Gong J-L, Liu Y, Wang X-Y, Liu Y-Y, Liu Z-F, Chen L, Zhang X-R, Tu D-Z (2012) Simultaneous adsorption of atrazine and $\mathrm{Cu}$ (II) from wastewater by magnetic multi-walled carbon nanotube. Chem Eng J 211:470-478

Tashakor M, Yaacob WZW, Mohamad H (2011) Speciation and availability of Cr, Ni and Co in serpentine soils of Ranau, Sabah. Am J Geo Sci 2(1):4-9

Tashakor M, Hochwimmer B, Brearley FQ (2017) Geochemical assessment of metal transfer from rock and soil to water in serpentine areas of Sabah (Malaysia). Environ Earth Sci 76(7):281

Van Den Berg G, Loch J (2000) Decalcification of soils subject to periodic waterlogging. Eur J Soil Sci 51(1):27-33

Van Gestel CA (2008) Physico-chemical and biological parameters determine metal bioavailability in soils. Sci Total Environ 406(3):385395

Vashisth A, Nagarajan S (2010) Effect on germination and early growth characteristics in sunflower (Helianthus annuus) seeds exposed to static magnetic field. J Plant Physiol 167(2):149-156

Vithanage M, Rajapaksha AU, Oze C, Rajakaruna N, Dissanayake C (2014) Metal release from serpentine soils in Sri Lanka. Environ Monit Assess 186(6):3415-3429

Wei W, Ma R, Sun Z, Zhou A, Bu J, Long X, Liu Y (2018) Effects of mining activities on the release of heavy metals (HMs) in a typical mountain headwater region, the Qinghai-Tibet Plateau in China. Int J Environ Res Public Health 15(9):1987

Wu H, Zeng G, Liang J, Chen J, Xu J, Dai J, Li X, Chen M, Xu P, Zhou Y (2016) Responses of bacterial community and functional marker genes of nitrogen cycling to biochar, compost and combined amendments in soil. Appl Microbiol Biotechnol 100(19):8583-8591

Wu H, Lai C, Zeng G, Liang J, Chen J, Xu J, Dai J, Li X, Liu J, Chen M (2017) The interactions of composting and biochar and their implications for soil amendment and pollution remediation: a review. Crit Rev Biotechnol 37(6):754-764

Xu X, Cao X, Zhao L, Zhou H, Luo Q (2014) Interaction of organic and inorganic fractions of biochar with $\mathrm{Pb}$ (II) ion: further elucidation of mechanisms for $\mathrm{Pb}$ (II) removal by biochar. RSC Adv 4(85):4493044937

Ye-Tao T, Teng-Hao-Bo D, Qi-Hang W, Shi-Zhong W, Rong-Liang Q, Ze-Bin W, Xiao-Fang G, Qi-Tang W, Mei L, Tong-Bin C (2012) Designing cropping systems for metal-contaminated sites: a review. Pedosphere 22(4):470-488

Zeng F, Ali S, Zhang H, Ouyang Y, Qiu B, Wu F, Zhang G (2011) The influence of $\mathrm{pH}$ and organic matter content in paddy soil on heavy metal availability and their uptake by rice plants. Environ Pollut 159(1):84-91

Zeng G, Wu H, Liang J, Guo S, Huang L, Xu P, Liu Y, Yuan Y, He X, He $Y$ (2015) Efficiency of biochar and compost (or composting) combined amendments for reducing $\mathrm{Cd}, \mathrm{Cu}, \mathrm{Zn}$ and $\mathrm{Pb}$ bioavailability, mobility and ecological risk in wetland soil. RSC Adv 5(44):3454134548

Zhang X, Wang H, He L, Lu K, Sarmah A, Li J, Bolan NS, Pei J, Huang $\mathrm{H}$ (2013) Using biochar for remediation of soils contaminated with heavy metals and organic pollutants. Environ Sci Pollut Res Int 20(12):8472-8483

Zheng S, Zhang M (2011) Effect of moisture regime on the redistribution of heavy metals in paddy soil. J Environ Sci 23(3):434-443 